\title{
PENGALAMAN PASIEN PERTAMA KALI TERDIAGNOSIS HIV/AIDS: STUDI FENOMENOLOGI DALAM PERSPEKTIF KEPERAWATAN
}

\author{
Welly Vitriawan*, Ratna Sitorus ${ }^{* *}$, Yati Afiyanti ***
}

\begin{abstract}
Abstrak
Suatu studi fenomenologi telah dilakukan untuk mengeksplorasi berbagai pengalaman pasien pertama kali terdiagnosis HIV/AIDS termasuk pengalaman menerima pelayanan kesehatan dari para praktisi kesehatan. Data studi ini diperoleh dari 6 partisipan, dikumpulkan melalui wawancara formal tidak berstruktur yang mendalam sebanyak dua kali di ruang rawat khusus HIV/AIDS RS X di Jakarta. Wawancara direkam kemudian dibuat dalam bentuk transkrip wawancara. Hasil penelitian mengungkapkan variasi berbagai pengalaman pasien pertama kali terdiagnosis HIV/AIDS. Setiap pasien dalam studi ini saat pertama kali terdiagnosis HIV/AIDS mengalami stress. Pasien juga mengalami proses berduka. Berbagai mekanisme koping dan adaptasi telah dilakukan pasien. Selain itu setiap pasien pertama kali terdiagnosis HIV/AIDS membutuhkan dukungan dari lingkungan sekitarnya terutama dari keluarga, pasangan, teman terdekat, dan petugas kesehatan. Pasien juga membutuhkan pelayanan keperawatan termasuk membutuhan perawat yang bersikap baik dan komunikatif. Hasil studi ini diharapkan perawat medikal bedah akan lebih memahami harapan pasien HIV/AIDS untuk dapat meningkatkan kualitas hidup.
\end{abstract}

Kata kunci: berduka, HIV/AIDS, pengalaman pertama kali terdiagnosis, stress.

\section{Abstract}

This a phenomenology study which aims to understand the diverse of patients' first time experiences when they were diagnosed with HIV/AIDS included experience accepted of health care. The data collection from six participants with deep interviewed in the $X$ Hospital in Jakarta. Interview recorded thus transcripted. The findings showed that the patients' first time experiences when diagnosed with HIV/AIDS were depicted emotionally and filled with thematic expressions. It was concluded from this study that the physical, psychological and social stress were considered as the first time experiences of patients when diagnosed with HIVIAIDS. Whilst the first grieving process experienced by the patients. The coping mechanisms identified as the first time experiences were the openness to others, self motivated, and struggled to adapt to the any circumstances. The research findings suggested that the first time experiences of every patient when diagnosed with HIV/AIDS required supports primarily from relatives, spouse, significant friends and health care providers. The needs to the nursing care and good behaviors and communication of nurses were also included as the first needs and expectations of the patients to the nurses. Furthermore, the study also made suggestions that supports, recognition and improvement of the nursing service provided for the first time experience of patients being diagnosed with HIV/AIDS, in turn, would lead to the better patients' live and reassure the quality of nursing care

Key words: first time experience were diagnosed, grieving, HIV/AIDS, stress.

\section{LATAR BELAKANG}

Aquired Immune Defficiency Syndrome (AIDS) merupakan kumpulan gejala penyakit yang disebabkan oleh Human Immunodeficiency Virus (HIV) yang menyerang sistem kekebalan tubuh (Noer, 1996). Penyakit ini menjadi ancaman bagi individu, keluarga, dan masyarakat karena dampak yang ditimbulkannya.
Pasien diperkirakan mengawali proses berduka saat mendapatkan informasi pertama kali terdiagnosis HIV/AIDS. Hal ini menyebabkan stress fisik, psikologis, dan sosial. Keterlibatan emosi membangkitkan penolakan (denial) terhadap diagnosis, kemarahan (anger), penawaran (bargaining), dan depresi (depression) namun pada akhirnya pasien harus menerima kenyataan (acceptance). Selain itu pasien merasa tidak nyaman dan 
beranggapan bahwa mengidap HIV adalah memalukan dan sebagai akibatnya mereka khawatir dipermalukan, dihindari, didiskreditkan, dan ditolak (O’Neill et al., 2003).

Elemen pendukung yang dibutuhkan dalam penanganan HIV/AIDS adalah tersedianya tenaga kesehatan terlatih. WHO mengatakan bahwa diperlukan upaya untuk menjamin tenaga kesehatan yang memadai dalam memberikan akses menyeluruh bagi pencegahan, pengobatan, perawatan, dan dukungan pada pasien HIV/AIDS hingga tahun 2010 (WHO, 2006; Depkes RI, 2006). Salah satu elemen pendukung tersebut perawat yang cakap dan mampu mengelola pasien HIV/AIDS secara komprehensif. Menurut Nurachmah (2004), perawat merupakan bagian dari tim pelayanan kesehatan yang memberikan asuhan keperawatan secara holistik.

Untuk meningkatkan keahlian dan pencapaian kompetensi profesi perawat pada pelayanan keperawatan di Indonesia, dikembangkan pendidikan keperawatan yang lebih tinggi yang diharapkan dapat memenuhi kebutuhan pelayanan profesional dengan diselenggarakannya Program Magister Keperawatan dan Program Ners Spesialis untuk dapat melaksanakan tugas-tugas berdasarkan peran mandiri sebagai Ners Spesialis, antara lain: 1) sebagai pemberi asuhan keperawatan; 2) sebagai peneliti, dan; 3) sebagai pendidik. Peran ini merupakan perwujudan menjunjung tinggi harkat manusia dan meningkatkan derajat kesehatan, ketiganya merupakan peran yang harus dipertanggungjawabkan kepada profesi, keilmuan, bangsa, dan kepada Tuhan YME.

Sejumlah penelitian yang dilakukan di Amerika Serikat, Afrika Selatan, Uganda dan Puerto Rico telah melaporkan tentang pengalaman pasien HIV/ AIDS, stigma, dukungan dan peran perawat dalam mengelola pasien HIV/AIDS di rumah sakit maupun di masyarakat (Holzemer, 1998; Sherman, 2000; Carter, 2002; Ciambrone, 2002; Mallory, 2002; Diaz \& Alfonso, 2003; Vosvick, 2003). Sementara itu masih sangat sedikit informasi tentang pasien
HIV/AIDS di Indonesia yang menceritakan pengalamannya saat pertama kali terdiagnosis. Selain itu, belum banyak informasi yang menyatakan bahwa pasien HIV/AIDS di Indonesia dapat mengalami stress fisik, psikologis dan sosial akibat informasi medis yang didapat dan selama mereka menjalani sakit.

Dalam studi ini, peneliti menggunakan berbagai penjelasan yang diungkapkan oleh sejumlah pasien HIV/AIDS di RS X Jakarta yang mengekspresikan berbagai perasaan, pikiran, dan pengalaman mereka saat pertama kali terdiagnosis HIV/AIDS.

\section{METODOLOGI}

Studi ini mempelajari pengalaman pasien pertama kali terdiagnosis HIV/AIDS dengan menitikberatkan pada arti atau makna hidup pasien dalam menjalani sakit. Fenomena yang mendasarinya adalah respon fisik, psikologis, dan sosial yang terjadi saat pertama kali terdiagnosis. Dengan fokus penelitian kualitatif pada kedalaman dan proses, penelitian ini hanya melibatkan 6 partisipan (Poerwandari, 2005).

Data studi ini dikumpulkan melalui wawancara formal tidak berstruktur (unstructured formal interviews) yang mendalam sebanyak dua kali dengan para partisipan. Peneliti juga membuat catatan lapangan (field notes) untuk lebih menjamin percapaian hasil deskripsi yang komprehensif dan keakuratan hasil deskripsi tersebut (Streubert \& Carperter, 1999).

Analisis data dilakukan setiap selesai mengumpulkan data dari satu partisipan. Transkriptranskrip dari hasil wawancara dan catatan lapangan (field notes) yang telah dibuat peneliti secara bersamaan dianalisis dengan teknik analisis spesifik dengan menggunakan pendekatan analisis selektif dan focusing (The selective or high lighting approach) untuk mengungkap dan mengisolasikan berbagai aspek tematik dari fenomena-fenomena yang disoroti dalam studi ini. 


\section{HASIL PENELITIAN}

\section{Karakteristik Partisipan}

Usia partisipan 24-40 tahun dan tinggal di DKI Jakarta. Latar belakang pendidikan mereka yaitu 4 tamat SMU dan 2 sarjana. Pekerjaan partisipan bervariasi yaitu 1 karyawan, 1 sales freelance, 1 mahasiswa, dan 3 orang tidak bekerja. Agama yang dianut partisipan adalah 3 Islam dan 3 Kristen. Status perkawinan partisipan yaitu 5 belum kawin dan 1 sudah berkeluarga selama 1 bulan. Ketika diwawancarai, seorang partisipan mengakui memiliki pasangan homoseksual dengan orang asing, sedangkan 5 orang lainnya mengakui menggunakan NAPZA dengan alat suntik. Hasil wawancara lainnya yaitu 3 partisipan telah terdiagnosis HIV sekitar 4 bulan yang lalu dan 3 orang lainnya sekitar 5 bulan yang lalu dengan tempat pemeriksaan HIV di beberapa rumah sakit di Jakarta dan Bandung.

\section{GAMBARAN BERBAGAI PENGALAMAN PARTISIPAN PERTAMA KALI TERDIAGNOSIS HIV/ AIDS}

\section{Analisis Tematis}

1. Setiap pasien pertama kali terdiagnosis HIVI AIDS mengalami stress.

Seorang partisipan mengungkapkan stress saat pertama kali dirinya terdiagnosis HIV/AIDS yang menyebabkan ketidakseimbangan, gangguan fungsi dan ketidaknyaman fisik saat pertama kali terdiagnosis HIV/AIDS. Seperti ungkapan salah satu partisipan:

Secara fisik saya sehat waktu itu tapi pas tahu saya dideteksi HIV ... lemes mas, keluar keringet dingin, jantung saya deg-degan sakit rasanya, saya seperti lumpuh, kakiku dingin.

Selain itu 2 partisipan yang mengalami stress psikologis yaitu merasa tertekan dan merasa buruk. Sedangkan stress sosial yang terjadi pada sebagian besar partisipan adalah merasa tidak nyaman dan beranggapan bahwa mengidap HIV adalah memalukan.
2. Berduka dialami pasien pertama kali terdiagnosis HIV/AIDS.

Semua partisipan dalam studi ini mengawali berduka dengan penolakan terhadap diagnosis HIV. Berikut ini adalah ungkapan partisipan tersebut:

... yang saya ingat saya sulit menerima, rasanya saya ingin meledak. Saya tidak yakin dan gimana ... benar nggak sih hasil itu. Apa mungkin benar hasil saya bukan punya orang lain. Saya baca nama saya, hasil test, saya baca nama saya lagi dan berulangulang. Sampai saya perhatikan semua sudut surat kalau-kalau test ini bukan milik saya.

Selain itu kebanyakan partisipan mengungkapkan kemarahan dan menyalahkan orang lain. Terdapat 2 partisipan mengungkapkan pengalamannya pada fase penawaran. Selanjutnya semua partisipan masuk dalam fase depresi yang diasosiasikan dengan frustasi, bersedih, bingung, ketakutan, dan menyalahkan diri sendiri. Para partisipan menganggap sedang menghadapi kematian mereka sendiri atau ketidakmampuan menjalani kehidupan selanjutnya. Berikut petikan ungkapan salah satu partisipan:

Ya ... saya merasa saya sudah tidak berguna nggak ada yang bisa saya lakukan. Habis sudah harapan saya kedepannya. Takut sekali, ga bisa dibayangkan. Takut mati. Pasti saya akan menderita kalo belum mati. Jadi saya menunggu ajal saja.

Menurut salah satu partisipan, tidak ada lagi yang dapat dilakukan karena sudah tidak mempunyai harapan sehingga pada akhirnya semua partisipan menerima kenyataan hidupnya dan menyerahkan sepenuhnya kepada Tuhan YME. 
3. Berbagai mekanisme koping dan adaptasi pasien pertama kali terdiagnosis HIV/AIDS.

Beberapa partisipan berupaya terbuka dengan orang lain mengenai kondisinya dan berusaha untuk mensemangati diri sendiri dari keterpurukan dan dari masalah yang dihadapi. Berikut ungkapan partisipan tersebut:

Saya kan nggak bisa saya pendam sendiri karena masalah ini kan cukup besar karena nanti efeknya nggak cuma ke saya sendiri tapi dampaknya kan kekeluarga. Jadi saya harus ngomong ke orangtua ... waktu itu saya cerita sama ibu ... waktu itu saya deketi ibu pas saya sudah agak tenang mas, saya coba cerita sama ibu kalo saya sebenarnya seperti ini...

Ungkapan lain yang partisipan sampaikan adalah mencoba menyesuaikan diri dengan lingkungan.

4. Setiap pasien pertama kali terdiagnosis HIVI AIDS membutuhkan dukungan dari lingkungan sekitarnya.

Semua partisipan mengungkapkan pentingnya dukungan keluarga dan merupakan kelompok pertama yang dihubungi partisipan saat pertama kali terdiagnosis HIV/AIDS, ungkapan partisipan sebagai berikut:

... mereka bener-bener mencintai saya ... saya yakin mereka sedih, saya bilang kalau mereka harapan satu-satunya saya ... saya mohon bantu saya. Sebenernya mas saya takut kalau saya meninggal tiba-tiba dan keluarga bertanya-tanya kenapa perlakuan jenasah saya berbeda dengan jenasah lainnya. Jadi mereka harus tahu segera ... ya mas saya harus siap-siap mati kalo saya mati kan mereka yang mengurus.

Selain itu, para partisipan membutuhkan dukungan dari pasangannya sebagai orang yang dapat dipercaya selama ini. Selanjutnya dukungan teman terdekat seperti teman kantor, bersosialisasi dan teman sesama pengidap HIV/ AIDS merupakan kelompok berikutnya yang dibutuhkan. Sama halnya dengan yang di atas, kebutuhan dukungan dari petugas kesehatan merupakan salah satu kelompok yang dicari oleh partisipan untuk mendapatkan pengobatan terbaik.

5. Berbagai kebutuhan pelayanan keperawatan dan harapan pasien pertama kali terdiagnosis HIV/AIDS.

Semua partisipan mengungkapkan penerimaan yang cukup baik pada pelayanan keperawatan, namun partisipan menaruh harapan kepada perawat untuk lebih menghargai pasien sebagaimana manusia seutuhnya. Seperti ungkapan berikut:

Saya perlu dirawat mas ... ya saya pikir semuanya sudah baik menurut saya mungkin nggak tahu ya aku sih menjalaninya sesuai apa yang mereka katakan aja ... Ya kalau ada ... seperti pemeriksaan ... maksud saya, saya cuma nunggu aja diperiksa dan minum obat.

Selain itu setiap partisipan mengungkapkan kebutuhannya terhadap perawat yang bersikap baik dan komunikatif pada saat pertama kali terdiagnosis. Kemudian partisipan mengharapkan perlunya meningkatkan mutu pelayanan keperawatan ke depannya lebih baik.

\section{PEMBAHASAN}

Stress merupakan respon tubuh yang tidak spesifik terhadap setiap kebutuhan yang terganggu, suatu fenomena universal yang terjadi dalam kehidupan yang tidak dapat dihindari, kemungkinan besar setiap pasien HIV/AIDS mengalaminya, stress memberi dampak secara total pada partisipan yaitu terhadap fisik, psikologis, dan sosial. Semua pasien mengalami ketegangan hidup, yang diakibatkan adanya tuntutan dan tantangan, kesulitan, ancaman ataupun ketakutan terhadap bahaya kehidupan yang semakin sulit dipecahkan. 
Stress yang berlarut-larut dan dalam intensitas yang tinggi dapat memperberat penyakit fisik dan mental pasien, yang akhirnya dapat menurunkan produktifitas kerja dan hubungan interpersonal (Hubbard, 2006c). Selain itu pasien pertama kali terdiagnosis HIV/AIDS juga mengalami berduka. Berdasarkan kerangka kerja stages of dying oleh Kubbler-Ross (1969), proses berduka itu sendiri melalui 5 tahap. Ditinjau dari hasil studi ini, pada fase penolakan, pasien menolak untuk percaya bahwa sebuah kehilangan telah terjadi. Ungkapan partisipan tersebut didukung oleh penelitian Mallory (2002), tentang pengisolasian wanita Afrika Amerika yang mengidap HIV. Hasil penelitian ini melaporkan bahwa telah terjadi penolakan terhadap diagnosis, depresi wanita Afrika Amerika pengidap HIV dan ketidaknyamanan menyampaikan pendapat bila menderita HIV. Wanita-wanita tersebut mengungkapkan pentingnya memahami perasaan dan keinginan wanita Afrika Amerika pengidap HIV.

Pada fase kemarahan, pasien mempertahankan kehilangan dan mungkin bertindak lebih pada setiap orang dan segala sesuatu yang berhubungan dengan lingkungan. Pada fase ini pasien lebih sensitif sehingga mudah sekali tersinggung dan marah. Hal ini merupakan koping individu untuk menutupi perasaaan kecewa dan merupakan manifestasi dari kecemasannya menghadapi kehilangan. Sedangkan pada fase penawaran ada semacam penundaan tentang kenyataan kehilangan.

Seseorang mungkin berusaha untuk membuat cara yang sama untuk mencegah kehilangan. Pasien mencari cara untuk mencoba membandingkan suatu kondisi selama fase ini. Tujuan pembandingan ini adalah untuk mencoba mencari pembenaran atas alasan perasaannya. Salah satu pasien pada studi ini sering kali mengungkapkan kata-kata penawaran dalam menceritakan pengalamannya yang menunjukkan pasien telah melalui fase ini. Pada fase depresi terjadi ketika kehilangan diketahui dan hubungan signifikannya menjadi lebih jelas. Fase ini mungkin dikaitkan dengan kesendirian dan penarikan diri secara keseluruhan.
Hasil studi ini juga didukung oleh penemuan Carter (2002), dalam penelitiannya melaporkan bahwa depresi dan kegelisahan dialami oleh sebagian yang sangat besar pada pasien HIV/AIDS. Sekitar $72 \%$ mengatakan mereka mengalami depresi, 65\% mengalami kegelisahan, dan $48 \%$ insomnia. Selain itu pada fase penerimaan, sikap penerimaan telah tercapai. Reaksi fisiologis menurun dan interaksi sosial dimulai lagi. Sikap ini ada bila seseorang mampu menghadapi kenyataan daripada hanya menyerah pada pengunduran diri atau tidak ada harapan.

Berbagai mekanisme koping dan adaptasi terhadap lingkungan telah dicoba pasien saat pertama kali terdiagnosis. Dari temuan studi ini, beberapa pasien menangis dan melamunkan kehidupannya ke depan. Setelah mulai pada fase penerimaan, pasien mencoba berbicara dan terbuka dengan orang lain seperti keluarga dan orang lain. Yang perlu diperhatikan beberapa pasien mengalami kesulitan dengan keterbukaan tentang status terinfeksi HIV-nya terhadap keluarga, komunitas/ masyarakat atau pun tempat kerja (Murni, 2003).

Sebuah penelitian yang dapat dipertimbangkan dengan hasil studi ini yang berkaitan dengan penggunaan koping dan adaptasi adalah penelitian tentang hubungan fungsional kualitas hidup, strategi koping dengan stress pada pasien HIV/ AIDS. Peneliti menguji faktor-faktor yang berhubungan dengan 4 dimensi fungsional kualitas hidup (fungsi fisik, energi/ kelelahan, fungsi sosial, dan fungsi peran). Hasil penelitian ini melaporkan bahwa sebagian besar menggunakan strategi koping maladaptif dihubungkan dengan tingkat energi yang rendah dan fungsi sosial yang rusak. Harapan intervensi dikembangkan berdasarkan strategi koping adaptif yang didasarkan pada aspek kualitas hidup pasien HIV/AIDS (APA, 1993; Vosvick, 2003).

Selanjutnya dalam studi ini, pasien berusaha menyemangati diri sendiri dan berupaya untuk dapat melanjutkan hidupnya dengan lebih bermakna berdasarkan kejadian-kejadian yang telah dilaluinya 
sebelum, selama dan setelah terdiagnosis HIV positif. Semangat hidup ini timbul bersamaan dengan pulihnya kesadaran terhadap diri sendiri, kebutuhan dan peran lingkungan yang membentuk serta proses menerima kenyataan hidup. Selanjutnya peneliti juga menemukan beragam penyesuaian diri pasien terhadap lingkungan.

Dukungan yang diharapkan pasien setelah terdiagnosis HIV/AIDS berasal dari keluarga, pasangan, teman terdekat dan petugas kesehatan. Sebagian besar pasien berkeinginan untuk membagi kabar ini dengan seseorang yang dekat dengannya. Setelah memberi tahu orang lain, beberapa pasien mendapatkan reaksi yang positif dan bermanfaat, tetapi ada juga yang mendapatkan kekecewaan atau lebih buruk dari itu. Menurut penuturan beberapa pasien, harus benar-benar yakin bahwa orang yang akan diberi tahu dapat dipercaya.

Hasil studi ini ternyata sesuai dengan penelitian yang dilakukan oleh Ciambrone (2002), dalam studinya peneliti menekankan pada pentingnya pemberian dukungan informal pada pasien yang menderita penyakit kronik, penting sekali untuk memahami secara mendalam kebutuhan dan dampak pada wanita dengan HIV/AIDS yang dikemas melalui sebuah jaringan kerja informal. Hasil penelitian ini melaporkan bahwa partisipan memiliki seorang pendukung selama mengidap HIV/ AIDS, biasanya keluarga dekat atau seseorang yang memiliki ikatan emosional. Kelompok pendukung lain yang dicari oleh pasien saat pertama kali terdiagnosis HIV/AIDS adalah petugas kesehatan untuk menentukan pengobatan, status kesehatan dan apa yang harus dilakukan pasien dalam menjalani sakit. Selanjutnya setiap pasien membutuhkan pelayanan keperawatan yang komprehensif dan holistik baik dalam memberikan pelayanan maupun sikap yang ditunjukan perawat dan berharap mutu pelayanan keperawatan dapat ditingkatkan dalam menangani HIV/AIDS.

Hal ini didukung pula oleh penelitian Smith \& Debus tahun 1993 dalam Aulia (1994), tentang peranan penelitian kualitatif dalam pencegahan AIDS yang membahas reaksi emosional para petugas kesehatan (dokter, perawat, tenaga laborat, dan ahli gizi) yang menangani masalah infeksi HIV/AIDS. Kemudian hasil penelitian ini melaporan tentang pemilihan jenis dan cara penyampaian informasi yang tepat pada pasien HIV/AIDS. Berdasarkan hasil temuan dalam studi ini perawat bersikap baik dan komunikatif terhadap pasien. Hal ini dapat diluruskan bahwa perawat selalu mencari bentuk yang tepat agar informasi yang dimilikitentang kesehatan pasien dapat tersampaikan (Feris, 2001).

\section{KESIMPULAN}

Pengalaman pasien pertama kali terdiagnosis HIV/AIDS berdampak pada aspek fisik, psikologis dan sosial, antara lain setiap pasien saat pertama kali terdiagnosis HIV/AIDS mengalami stress dan berduka pada saat itu. Setiap pasien menggunakan berbagai mekanisme koping dan adaptasi. Selain itu setiap pasien pertama kali terdiagnosis HIV/ AIDS membutuhkan dukungan dari lingkungan sekitarnya. Berbagai kebutuhan dan harapan pasien pertama kali terdiagnosis HIV/AIDS terhadap pelayanan keperawatan yang selanjutnya dapat membantu pasien dengan HIV/AIDS meningkatkan kualitas hidupnya $(\mathrm{HH})$.

* Welly Vitriawan, S.Kep. SH., M.Kep.: Staf Akademik Poltekes Malang, Jawa Timur

Dr. Ratna Sitorus, SKp. M.App.Sc.: Staf Akademik Kelompok Keilmuan Keperawatan Medikal Bedah Fakultas Ilmu Keperawatan Universitas Indonesia

*** YatiAfiyanti, SKp. MN: StafAkademik Kelompok Keilmuan Keperawatan Maternitas Fakultas Ilmu Keperawatan Universitas Indonesia 


\section{KEPUSTAKAAN}

American Psychiatric Association (APA). (1993). Coping with HIV and AIDS. http:// www.thebody.com/sitemap.html, December 1993. Diperoleh 1 September 2006.

Aulia, H. (1994). Pencegahan AIDS melalui promosi kesehatan: Masalah yang sensitive. Bandung: Penerbit ITB.

Carter, M. (2002). Depression and HIV/AIDS. Journal of Advanced Nursing. 30 (4), 825-834.

Ciambrone, D. (2002). Informal networks among women with HIV/AIDS: Present spport and future prospects. Qualitative health research, Vol.12 No. 7, September 2002, 876-896.

Ferris, FD., Flannery, JS., McNeal, HB., Morisette, MR., Cameron, R., \& Bally, GA. (2001). A comprehensive guide for the care of persons with HIV disease. Modul 4: Palliative Care. Toronto, Ontario: Mount Sinai Hospital and Casey House Hospice.

Hubbard, MJ. (2006c). Nursing care of the HIVinfected inmate: Mental health issues in HIVinfected inmates. Module 7. New York: Albany Medical College
Mallory, C. Miles, M.S. Davis, D.H. (2002).Reciprocity and retaining African-American women with HIV in research. W.B. Saunders Company

Noer, S. (1996). Buku ajar ilmu penyakit dalam Jilid I. (Edisi Ketiga). Jakarta: Balai Penerbit FKUI.

Nurachmah, E. (2004). Perawat, professionalisme, dan peluang kerja. Jakarta: Program Pascasarjana Fakultas Ilmu Keperawatan Univesitas Indonesia. Makalah tidak dipublikasikan.

O'Neill et al. (2003). A clinical guide to supportive and palliative care for HIV/AIDS. USA: Department of Health and Human Services

Poerwandari, E.K. (2005). Pendekatan kualitatif dalam penelitian psikologi. Jakarta: LPSP3 UI.

Sherman D.W. (2000). Experiences of AIDSdedicated nurses in alleviating the stress of AIDS caregiving. Journal of Advanced Nursing, 31(6), 1501-1508.

Streubert, HJ. Carpenter, DR. (1999). Qualitative research in nursing: Advancing the humanistic imperative. ( $2^{\text {nd }}$ Edition). Philadelphia: Lippincott Williams \& Wilkin.

Vosvick, M. et al. (2003). Relationship of functional quality of life to strategies for coping with the stress of living with HIV/AIDS. Journal Psichosomatic 44:51-58, February 2003. Academy of Psichosomatic Medicine. 